\title{
CRUDE GLYCERIN IN THE DIETS OF CONFINED LAMBS: PERFORMANCE, CARCASS TRAITS AND ECONOMIC FEASIBILITY
}

\author{
GLICERINA BRUTA NA DIETA DE CORDEIROS CONFINADOS: DESEMPENHO, \\ CARACTERÍSTICAS DE CARCAÇA E VIABILIDADE ECONÔMICA
}

\section{Marco Antonio Previdelli ORRICO JUNIOR ${ }^{1}$; Flavio Duilio Eugênio BOTTINI FILHO²; Fernando Miranda de VARGAS JUNIOR ${ }^{1}$; Ana Carolina Amorim ORRICO ${ }^{1}$; José Carlos da Silveira OSÓRIO ${ }^{3}$}

1. Professor Adjunto, Faculdade de Ciências Agrárias da Universidade Federal da Grande Dourados, Dourados, MS, Brasil. marcoorrico@yahoo.com.br; 2. Mestre em Zootecnia, Faculdade de Ciências Agrárias da Universidade Federal da Grande Dourados, Dourados, MS, Brasil. 3. Professor Visitante, Doutor, Faculdade de Ciências Agrárias da Universidade Federal da Grande Dourados, Dourados, MS, Brasil

\begin{abstract}
The crude glycerin is a byproduct of the biodiesel industry which has high levels of glycerol and can be utilized by ruminants for obtaining energy. This research was conducted in order to evaluate the performance, carcass characteristics and economic feasibility of lambs fed diets containing crude glycerin replacing ground corn. 24 non-castrated lambs (Pantaneiro racial grouping) at 90 days of age and average body weight of $20.02 \pm 1.5 \mathrm{~kg}$ were used. We evaluated diets containing 0,2.5, 5.0 and 7.5\% inclusion of crude glycerin on dry matter of the diet replacing ground corn. The parameters evaluated were the consumption of dry matter and nutrients, weight gain, feed conversion, biometric measurements in vivo and carcass characteristics, in addition to the cost of the diet based on the carcass production. Animals reduced dry matter intake as doses of crude glycerin were increased. However, no differences to the weight gain of the animals were observed. Thus, animals fed crude glycerin showed better feed conversion rates and lower feeding cost which contributed to higher profit margin of the diets with crude glycerin. It is concluded that at the doses tested, the crude glycerin can be used in the diet of finishing lambs, however only at the level of $7.5 \%$ becomes economically feasible.
\end{abstract}

KEYWORDS: Production costs. Glycerol. Sheep. Byproduct.

\section{INTRODUCTION}

The crude glycerin is a byproduct generated from the production of biodiesel, which has key features such as high concentrations of glycerol, methanol and fatty acids. Along with the prospect of increased production of this biofuel also has grown a concern about the proper disposal of this byproduct (LARSEN et al., 2013; AVILASTAGNO et al., 2012).

Due to the high levels of glycerol and fat, crude glycerin can be used in ruminant diets as a source of energy replacing part of the corn in diets and thereby reducing the costs of feeding (PELLEGRIN et al., 2013; SANTANA JUNIOR et al., 2013). According to Meale et al. (2013) glycerol and lipids present in the crude glycerin are potential energy sources for animals. However little is known about the effect of crude glycerin on performance and carcass characteristics of sheep, and how its use reduces production costs.

Therefore the aim of the experiment was to evaluate the use of diets with $0,2.5,5.0$ and $7.5 \%$ crude glycerin in feeding of lambs raised in confinement, and their effects on performance and carcass characteristics of these animals, as well the economic feasibility of these diets.

\section{MATERIAL AND METHODS}

The experiment was conducted at the Sheep Research Center and Laboratory of Quality and Carcass Evaluation of Agricultural Sciences College, Federal University of Grande Dourados, MS. On the total, 24 intact male lambs of "Pantaneiro" breed, with an average age of 90 days and average body weight of $20.02 \pm 1.5 \mathrm{~kg}$ were used.

The experiment was conducted in a randomized block design with four treatments and six replications. The treatments tested were diets containing $0,2.5,5.0$ and $7.5 \%$ crude glycerin or 0 , $0.9,1.8$ and $2.7 \%$ glycerol in the dry matter of the diet.

The animals were housed in $2 \mathrm{~m}^{2}$ individual stalls with concrete floor covered with wood shavings, provided with feeder and nipple type drinkers and arranged in a covered area.

During the pre-experimental period the animals were identified, weighed, dewormed (Ivermectin 1\%) and subjected to adaptation to the installation, management and diets for a period of 10 days. 
The diets (Table 1) were formulated to

following the recommendations of NRC (2007). provide an average gain of $0.2 \mathrm{~kg} /$ day / animal,

Table 1. Content (\%) of experimental diets and chemical composition.

\begin{tabular}{lcccc}
\hline & \multicolumn{4}{c}{ \% Crude glycerin } \\
\cline { 2 - 5 } Composition (\%DM) & 0.0 & 2.5 & 5.0 & 7.5 \\
\hline Oat hay & 24.33 & 24.33 & 24.33 & 24.33 \\
Soybean, meal & 11.06 & 11.06 & 11.06 & 11.06 \\
Soybean, whole & 4.42 & 4.42 & 4.42 & 4.42 \\
Crude Glycerin* & 0.00 & 2.50 & 5.00 & 7.50 \\
Corn, ground & 58.62 & 56.12 & 53.62 & 51.12 \\
Limestone & 1.11 & 1.11 & 1.11 & 1.11 \\
Salt & 0.46 & 0.46 & 0.46 & 0.46 \\
\hline Chemical Composition & & & & 89.28 \\
\hline DM (\%) & 87.89 & 88.34 & 89.21 & 93.28 \\
OM (\% DM) & 93.94 & 94.25 & 93.76 & 24.24 \\
NDF (\% DM) & 24.92 & 24.69 & 24.47 & 14.24 \\
ADF (\% DM) & 14.54 & 14.44 & 14.34 & 6.72 \\
MM (\% DM) & 6.06 & 5.75 & 6.24 & 6.83 \\
CP (\% DM) & 16.15 & 15.90 & 15.65 & 5.26 \\
EE (\% DM) & 3.41 & 4.72 & DM & \\
\hline
\end{tabular}

$\mathrm{DM}=$ Dry matter; $\mathrm{OM}=$ Organic matter; $\mathrm{NDF}=$ Neutral detergent fiber $\mathrm{ADF}=$ Acid detergent fiber; $\mathrm{MM}=$ Mineral matter; $\mathrm{CP}=\mathrm{Crude}$ protein; EE=Ether extract; * composition: $3.63 \%$ moisture, $39.3 \%$ glycerol, $4.75 \%$ methanol, $47.3 \%$ fatty acids, $2 \% \mathrm{CP}, 12.1 \mathrm{mgNa} / \mathrm{kg}$, $372.28 \mathrm{mgK} / \mathrm{kg}, 68.25 \mathrm{mgCa} / \mathrm{kg}, 15.15 \mathrm{mgMn} / \mathrm{kg}, 171.63 \mathrm{mgP} / \mathrm{kg},<0.4 \mathrm{mgCd} / \mathrm{kg} \mathrm{e}<4.0 \mathrm{mgPb} / \mathrm{kg}$.

The animals were fed three meals daily: 8:00 am, 11:00 am and 16:00 pm. The food was provided ad libitum and recalculated every three days, to allow a leftover of $10 \%$ total ration. Every day, before the first meal the leftovers were weighed and sampled for evaluation of the DM and nutrients consumed by the animals. The samples were frozen and leftovers grouped into periods of 14 days (a composite sample/ animal /period) for subsequent nutrient analysis which were performed according to the methodology described by Silva \& Queiroz (2002).

Every 14 days, after fasting (food and water) for 16 hours, the animals were weighed on a digital scale to monitor weight gain and feed conversion. On this occasion also the body condition and biometric measurements were assessed: body length, chest girth, rump width, rump height and foreleg height, as described by Osório \& Osório, (2005).

Body condition was used as a criterion for slaughter and animals were slaughtered upon reaching the score between 2.5 (normal) to 3.0 (slightly fat) on a scale of 1 (too thin) to 5 (extremely fat), at intervals of 0.5 according to Osório \& Osório, (2005).

The slaughter of the lambs was conducted according to the guidelines of the Regulation of Industrial and Sanitary Inspection of Products of Animal Origin - RIISPOA (BRASIL, 2000).
Carcasses were evaluated according to the methodology proposed by Osório \& Osório, (2005) and the following parameters were evaluated: hot carcass weight, cold carcass weight, hot carcass yield, cold carcass yield, carcass external length, carcass internal length, leg length, leg width, leg depth, depth of chest, and fat conformation and score.

The costs of feeding were determined and economic feasibility of diets containing different levels of glycerin was evaluated considering only the daily carcass yield without accounting for other fixed and operating costs of the production of sheep system, since these would be the same in the five situations.

The data relating to parameters of animal performance and carcass characteristics were subjected to regression analysis and the initial body weight was used as a covariate. Orthogonal contrasts were used to assess the effects of linear and quadratic order of levels of crude glycerin. Nonparametric characteristics were evaluated through Kruskal - Wallis test, as described by (SAMPAIO, 2002). Analyses were performed using the SAEG 9.1 software (UFV, 2007).

\section{RESULTS AND DISCUSSION}

The consumption of DM (kg/day), percentage of body weight and metabolic weight) 
was reduced in a linear fashion with inclusion of

crude glycerin in the diets (Table 2).

Table 2. Nutrient intake and performance of lambs fed diets containing different proportions of crude glycerin replacing corn.

\begin{tabular}{|c|c|c|c|c|c|c|c|c|}
\hline \multirow{2}{*}{ Parameters } & \multicolumn{4}{|c|}{ Crude Glycerin (\%) } & \multirow{2}{*}{ Regression equation } & \multirow{2}{*}{$\mathrm{R}^{2}$} & \multirow{2}{*}{$\mathrm{P}$} & \multirow{2}{*}{$\mathrm{CV} \%$} \\
\hline & 0.0 & 2.5 & 5.0 & 7.5 & & & & \\
\hline $\mathrm{DM}(\mathrm{kg} / \mathrm{d})$ & 1.20 & 1.06 & 1.03 & 1.01 & $y=-0.0239 C G+1.1691$ & 0.53 & $<0.01$ & 8.65 \\
\hline $\mathrm{DM}(\% \mathrm{BW})$ & 4.20 & 3.94 & 3.68 & 3.66 & $y=-0.074 C G+4.1468$ & 0.33 & $<0.01$ & 8.90 \\
\hline $\mathrm{DM}\left(\mathrm{g} / \mathrm{BW}^{0,75}\right)$ & 94.10 & 88.20 & 85.50 & 84.05 & $y=-0.0013 C G+0.0927$ & 0.30 & $<0.01$ & 7.89 \\
\hline $\mathrm{CP}$ (kg/dia) & 0.195 & 0.169 & 0.170 & 0.156 & $\begin{array}{c}\mathrm{y}=0.0008 \mathrm{CG}^{2}-0.0109 \\
\mathrm{~GB}+0.1938\end{array}$ & 0.74 & $<0.01$ & 10.10 \\
\hline $\mathrm{CPB}(\% \mathrm{BW})$ & 0.661 & 0.610 & 0.612 & 0.564 & $\begin{array}{c}\mathrm{y}=0.0015 \mathrm{CG}^{2}-0.0244 \\
C G+0.6609\end{array}$ & 0.37 & $<0.01$ & 10.35 \\
\hline $\mathrm{EE}(\mathrm{kg} / \mathrm{d})$ & 0.033 & 0.036 & 0.047 & 0.057 & $\begin{array}{c}\mathrm{y}= \\
0.0004 \mathrm{CG}^{2}+0.0003 \mathrm{CG}+0 \\
.0318\end{array}$ & 0.91 & $<0.01$ & 4.12 \\
\hline $\mathrm{EE}(\% \mathrm{BW})$ & 0.157 & 0.180 & 0.235 & 0.289 & $\begin{array}{c}\mathrm{y}=0.002 \mathrm{CG}^{2}+0.0031 \mathrm{CG}+ \\
0.1516\end{array}$ & 0.92 & $<0.01$ & 3.94 \\
\hline NDF (kg/d) & 0.299 & 0.261 & 0.252 & 0.244 & $\mathrm{y}=0.264$ & - & 0.12 & 14.67 \\
\hline $\mathrm{NDF}(\% \mathrm{BW})$ & 1.422 & 1.285 & 1.263 & 1.242 & $y=1.303$ & - & 0.14 & 19.34 \\
\hline $\mathrm{ADF}(\mathrm{kg} / \mathrm{d})$ & 0.174 & 0.152 & 0.157 & 0.143 & $y=0.156$ & - & 0.21 & 15.89 \\
\hline $\mathrm{ADF}(\% \mathrm{BW})$ & 0.827 & 0.748 & 0.786 & 0.72 & $y=0.772$ & - & 0.19 & 21.34 \\
\hline FBW (kg) & 38.10 & 35.52 & 36.5 & 36.5 & $y=36.65$ & - & 0.07 & 8.07 \\
\hline DW (kg/d) & 0.22 & 0.20 & 0.21 & 0.23 & $\mathrm{y}=0.22$ & - & 0.22 & 8.46 \\
\hline $\mathrm{FC}(\mathrm{kg} / \mathrm{kg})$ & 5.30 & 5.10 & 4.79 & 4.41 & $y=-0.118 C G+5.351$ & 0.53 & 0.01 & 9.39 \\
\hline $\mathrm{TG}(\mathrm{kg})$ & 17.08 & 15.22 & 16.55 & 16.87 & $\mathrm{y}=16.43$ & - & 0.06 & 9.54 \\
\hline
\end{tabular}

DM, CP and NDF, ADF (kg/d) = consumption in kilograms per day; DM, CP and NDF, ADF (\% BW) = consumption related to body weight; DM $\left(\mathrm{g} / \mathrm{BW}^{0,75}\right)$ = consumption related to metabolic weight; FBW- Final body weight; DW- Daily weight gain; FC- Feed conversion; TG- Total gain; $\mathrm{R}^{2}=$ model coefficient of determination; $\mathrm{P}=$ significance value; $\mathrm{CV}(\%)=$ coefficient of variation.

The consumption values varied in the range from 1.20 to $1.01 \mathrm{~kg} \mathrm{DM} /$ day with doses of 0 and 7.5\% respectively. The decreasing of diets consumption along with the addition of crude glycerin may be related to one or more of the following factors: chemical satiety due to higher energy concentration of the diet, toxic effect caused by excess lipids and decreasing palatability of the mixture.

Ruminants when fed diets containing high content of grains, tend to regulate the intake depending on the amount of energy consumed (chemical mechanism of control of hunger and satiety). According to the data of Table 1, the ether extract ranged from 3.41 to $6.83 \%$ of diet DM, resulting in different concentrations of metabolizable energy. In a review Krehbiel et al. (2006) analyzed data from 49 experiments (a population of 243 cattle) providing the diets with different concentrations of metabolizable energy to the animals. The models showed that animals decreased DM intake in proportion to the increase of metabolizable energy of the diet, therefore, there was no difference in the total metabolizable energy intake.

The toxic effect of increased levels of lipids in the diet may also have contributed to the reduction in consumption. According Bosa et al. (2012) values above 5\% ether extract impact negatively in food degradation by rumen microorganisms (toxic effect) and therefore the intake. The fatty acid toxicity to the rumen microorganisms is related to their nature and polyunsaturated long chain fatty acids (vegetable oils type) are the most harmful (PALMQUIST; MATTOS, 2006).

Another factor that may have affected the animals consumption is the rancidity of fats present in the crude glycerin, whereas unsaturated fatty acids are more susceptible to rancidity process. One of the end products of rancidity are peroxides, which cause a characteristic odor and unpleasant taste in the diet, thereby reducing your intake by animals (BOSA et al., 2012). No analysis was 
performed to assess the degree of rancidity of crude glycerin, but it was possible to detect a characteristic odor of rancid fat once the glycerin used in this study was from disposal of oil and stored at room temperature.

The decrease in consumption of diets containing crude glycerin was also observed by Lage et al. (2010) in finishing lambs of Santa Inês breed. The authors observed that consumption ranged from 1.12 to $0.78 \mathrm{~kg} \mathrm{DM} /$ day, according to doses of 0 and $12 \%$ inclusion of crude glycerin, respectively, also following a negative linear model. For the authors, the low DM intake was obtained as a function of methanol present in the crude glycerin used $(8.7 \%)$, almost two-fold methanol concentration from crude glycerin used in this study $(4.7 \%)$. The total concentrations of methanol in the diets ranged from 0.00 to $0.03 \%$ of $\mathrm{DM}$, which according Jung \& Batal (2011) is not related to the reduced consumption and performance. Leão et al. (2012) reported that at low concentrations the methanol is converted to methane by rumen microorganisms thus avoiding possible poisoning of animals.

The CP intake showed the decreasing behavior according to the addition of crude glycerin as well as intake, however following a quadratic prediction model. From this model, the lower CP intake ( $\mathrm{kg} /$ day) was obtained at a dose of $7.5 \%$ crude glycerin. Although significant, the difference between the diet with highest ( $0 \%$ crude glycerin) and lowest (7.5\% crude glycerin) $\mathrm{CP}$ content was $0.7 \%$, which explains the similar weight gain between animals.

Despite lower intakes of DM and CP, the animals showed no differences in weight gain between the diets tested (Table 2), i.e., the animal requirements were met by the diets and the gains were close to those provided by NRC (2007). Probably the greatest energy density of diets containing crude glycerin (glycerol and ether extract) allowed to meet the energy needs of the animals even in the diets had the lowest intakes. In the experiment conducted by LAGE et al. (2010) weight gains decreased linearly with dose of crude glycerin present in the diet, especially for doses above $6 \%$ crude glycerin. According to the authors the poor performance was a result of reduced DM intake by the animals and the lack of conformity with the nutritional requirements for the desired gain $(0.3 \mathrm{~kg} /$ day $)$.

The feed conversion showed improvement due to the increase of crude glycerin in the diet. One reason for the reduction in the values of feed conversion is due to the glycerol present in crude glycerin is readily fermented in the rumen yielding propionate and /or absorbed directly through the rumen epithelium and metabolized in the liver to produce glucose (energy supply for animals), as stated by Parsons et al. (2009).

Another factor that may have contributed to improve the feed conversion was the highest content of fat present in the diets containing crude glycerin (Table 1), thus the energy densities of the diets were higher and contributed to the compensation in total energy intake. This can be seen in Table 2 where we observe higher ether extract intakes due to the addition of crude glycerin in diets. If provided in adequate quantities lipids may be important energy sources for ruminants, leading to increased weight gain and improved feed conversion. Evaluating the performance of lambs Fernandes et al. (2011) had weight gain and feed conversion of 0.24 and 0.16 $\mathrm{kg} / \mathrm{day}$ and 4.06 and 6.4 for diet with $6 \%$ ether extract (similar content of diet with the highest dose of crude glycerin used in this study) compared with diets containing $2.2 \%$ ether extract.

No differences were observed with respect to the consumption of NDF and ADF (Table 2) and this fact may be associated with small portion of forage in the diet $(24.33 \%$ of diet) and the similarity between the NDF and ADF in the experimental diet.

No differences were observed in the biometric measurements in vivo and carcass of lambs (Table 3). Probably this behavior is associated with weight gains which occurred in a similar manner for the diets, and due to standardization of the final weight of the animals, with the intention of slaughtering animals with similar conditions. It is noteworthy that animals of the same breed and age that have similar weight gains also have similar biometric features (COSTA et al., 2009).

As the carcass weight at slaughter was similar among the animals, the hot carcass weight, hot carcass yield, cold carcass weight and cold carcass yield were also similar. However, it is noteworthy that the cold carcass weight and cold carcass yield could have varied depending on the cooling losses, but this did not occur because there was no difference between the fat thicknesses of carcasses.

For the economic analysis, it was found that the use of crude glycerin is feasible only at $7.5 \%$, as it enables higher profit margin, $6.3 \%$ higher than the diet without the inclusion of crude glycerin (Table4). 
Table 3. Biometric measurements in vivo and the carcass of "Pantaneiro" lambs fed diets containing different proportion of crude glycerin replacing ground corn.

\begin{tabular}{|c|c|c|c|c|c|c|}
\hline \multirow[t]{2}{*}{ Parameters } & \multicolumn{4}{|c|}{ Crude Glycerin (\%) } & \multirow[t]{2}{*}{$\mathrm{P}$} & \multirow{2}{*}{$\begin{array}{l}\mathrm{CV} \\
(\%)\end{array}$} \\
\hline & .0 & .5 & .0 & .5 & & \\
\hline Body length $(\mathrm{cm})$ & 61.17 & 58.17 & 58.00 & 60.50 & 0.08 & 3.78 \\
\hline Chest length $(\mathrm{cm})$ & 18.67 & 18.17 & 18.17 & 18.33 & 0.90 & 3.85 \\
\hline Rump width (cm) & 18.67 & 18.17 & 17.33 & 18.33 & 0.06 & 7.92 \\
\hline Rump height $(\mathrm{cm})$ & 66.00 & 64.50 & 64.50 & 63.67 & 0.07 & 3.94 \\
\hline Foreleg height $(\mathrm{cm})$ & 64.00 & 62.17 & 62.17 & 61.50 & 0.13 & 2.98 \\
\hline Chest girth (cm) & 66.17 & 62.33 & 62.83 & 63.83 & 0.22 & 4.18 \\
\hline Body compactness $(\mathrm{kg} / \mathrm{cm})$ & 0.55 & 0.51 & 0.50 & 0.52 & 0.34 & 8.90 \\
\hline Body weigth at slaughter $(\mathrm{kg})$ & 38.10 & 35.52 & 36.50 & 36.50 & 0.06 & 13.02 \\
\hline Hot carcass weight $(\mathrm{kg})$ & 18.97 & 17.88 & 17.97 & 18.49 & 0.09 & 5.83 \\
\hline Hot carcass yield (\%) & 49.77 & 50.40 & 49.25 & 50.61 & 0.06 & 3.10 \\
\hline Cold carcass weight (kg) & 18.34 & 17.34 & 17.37 & 17.72 & 0.12 & 6.09 \\
\hline Cold carcass yield (\%) & 48.12 & 48.85 & 47.57 & 48.48 & 0.09 & 3.20 \\
\hline Cooling losses $(\%)$ & 3.32 & 3.02 & 3.33 & 4.16 & 0.10 & 8.90 \\
\hline Carcass external length $(\mathrm{cm})$ & 58.33 & 58.25 & 57.67 & 57.50 & 0.08 & 6.00 \\
\hline Carcass internal length $(\mathrm{cm})$ & 62.00 & 61.00 & 62.00 & 60.67 & 0.07 & 6.00 \\
\hline Length of leg $(\mathrm{cm})$ & 40.83 & 40.67 & 40.17 & 40.50 & 0.11 & 4.03 \\
\hline Width of leg $(\mathrm{cm})$ & 10.67 & 9.50 & 9.92 & 9.67 & 0.13 & 9.15 \\
\hline Depth of leg $(\mathrm{cm})$ & 14.17 & 14.42 & 14.42 & 13.83 & 0.09 & 7.09 \\
\hline Depth of chest $(\mathrm{cm})$ & 27.00 & 26.42 & 22.83 & 26.17 & 0.08 & 16.12 \\
\hline Conformation & 3.00 & 2.83 & 3.00 & 2.83 & 0.13 & 14.22 \\
\hline Fat score & 3.58 & 3.33 & 3.42 & 3.50 & 0.09 & 15.24 \\
\hline Carcass fat thickness (mm) & 1.83 & 1.81 & 1.78 & 2.22 & 0.24 & 27.37 \\
\hline
\end{tabular}

$\mathrm{P}=$ significance value; $\mathrm{CV} \%=$ coefficient of variation.

Table 4. Economic analysis of the experimental diets in relation to carcass gain of lambs and sensitivity analysis of the variation in the price of crude glycerin (\% price of ground corn) on the cost of carcass gain $(\mathrm{R} \$ / \mathrm{kg}$ carcass gain) fed diets containing different proportions of crude glycerin replacing corn.

\begin{tabular}{|c|c|c|c|c|}
\hline \multirow[b]{2}{*}{ Variable } & \multicolumn{4}{|c|}{ Crude Glycerin (\%) } \\
\hline & 0.0 & 2.5 & 5.0 & 7.5 \\
\hline Diet costs $(\mathrm{R} \$ / \mathrm{DM} \mathrm{kg})$ & 0.54 & 0.53 & 0.52 & 0.51 \\
\hline DM consumption $(\mathrm{kg} / \mathrm{d})$ & 1.20 & 1.06 & 1.03 & 1.01 \\
\hline Diet costs $(\mathrm{R} \$ /$ animal/d) & 0.64 & 0.56 & 0.53 & 0.51 \\
\hline Carcass gain $(\mathrm{kg} / \mathrm{animal} / \mathrm{d})$ & 0.109 & 0.101 & 0.103 & 0.116 \\
\hline Diet costs $(\mathrm{R} \$ /$ carcass kg) & 4.89 & 5.23 & 5.01 & 4.37 \\
\hline Profit margin $(\%)^{*}$ & 40.32 & 36.27 & 38.94 & 46.69 \\
\hline \multirow{2}{*}{ (\% corn price) } & \multicolumn{4}{|c|}{ Diet costs $(\mathrm{R} \$ /$ carcass $\mathrm{kg})$} \\
\hline & 0.0 & 2.5 & 5.0 & 7.5 \\
\hline 0 & 4.89 & 4.82 & 4.79 & 4.26 \\
\hline 20 & 4.89 & 4.84 & 4.84 & 4.33 \\
\hline 40 & 4.89 & 4.87 & 4.88 & 4.40 \\
\hline 60 & 4.89 & 4.89 & 4.94 & 4.47 \\
\hline 80 & 4.89 & 4.91 & 4.98 & 4.53 \\
\hline 100 & 4.89 & 4.94 & 5.03 & 4.60 \\
\hline 120 & 4.89 & 4.97 & 5.09 & 4.67 \\
\hline 140 & 4.89 & 4.99 & 5.13 & 4.74 \\
\hline
\end{tabular}




\begin{tabular}{lllll}
160 & 4.89 & 5.01 & 5.18 & 4.81 \\
180 & 4.89 & 5.04 & 5.23 & 4.87 \\
\hline
\end{tabular}

The prices of ingredients are referent to values with shipping included based on the dry matter of the diet. Oat hay R\$ 0.33/kg; ground corn, $\mathrm{R} \$ 0.53 / \mathrm{kg}$; soybean meal, $\mathrm{R} \$ 0.72 / \mathrm{kg}$; soybean whole, $\mathrm{R} \$ 1.30 / \mathrm{kg}$; crude glycerin, $\mathrm{R} \$ 0.17 / \mathrm{kg}$; (only shipping price, so it has no commercial value); salt, $\mathrm{R} \$ 1.2 / \mathrm{kg}$; Limestone, $\mathrm{R} \$ 0.20$. (*) Profit margin $=[($ carcass price $(\mathrm{R} \$ / \mathrm{kg})$ - diet cost $(\mathrm{R} \$ / \mathrm{kg})] /$ carcass price $(\mathrm{R} \$ / \mathrm{kg}) \mathrm{x} 100$. Considering a price of $\mathrm{R} \$ 8.20$ per $\mathrm{kg}$ of carcass.

The sensitivity analysis showed that when the price of crude glycerin reaches $60 \%$ of the price of corn the inclusion levels of 2.5 and $5 \%$ glycerin become unviable. While the level of $7.5 \%$ crude glycerin remains viable even when the price of crude glycerin is $180 \%$ the price of corn, i.e., even crude glycerin having a value above the price of corn, the benefit generated in food conversion offsets this cost.

\section{CONCLUSION}

The use of up to $7.5 \%$ crude glycerin replacing corn in the diet of lambs (Pantaneiro racial grouping) raised in confinement keeps the performance and meat production of these animals, but only at the level of $7.5 \%$ becomes economically feasible.

RESUMO: A glicerina bruta é um subproduto da indústria do biodiesel que apresenta elevados teores de glicerol que podem ser utilizados pelos ruminantes para obtenção de energia. Esta pesquisa foi realizada com o objetivo de se avaliar o desempenho, características de carcaça e viabilidade econômica de cordeiros alimentados com dietas contendo glicerina bruta em substituição ao grão de milho triturado. Foram utilizados 24 cordeiros não castrados do grupamento racial "Pantaneiro", com 90 dias de idade e peso corporal médio de 20,02 $\pm 1,5 \mathrm{~kg}$. Avaliou-se dietas contendo 0, 2,5, 5,0 e $7,5 \%$ de inclusão de glicerina bruta na matéria seca da dieta em substituição ao grão de milho triturado. Os parâmetros avaliados foram: consumo de matéria seca e de nutrientes, ganho de peso, conversão alimentar, medidas biométricas in vivo e características da carcaça, além do custo da dieta em função da produção de carcaça. Os animais reduziram o consumo de matéria seca à medida que aumentaram as doses de glicerina bruta. No entanto não foram observadas diferenças com relação ao ganho de peso dos animais. Desta forma os animais alimentados com glicerina bruta apresentaram melhores índices de conversão alimentar e menor custo com a alimentação o que contribuiu para maior margem de lucro das dietas com glicerina bruta. Conclui-se que nas doses testadas a glicerina bruta pode ser utilizada na dieta de cordeiros em terminação.

PALAVRAS-CHAVE: Custo de produção. Glicerol. Ovinos. Subproduto.

\section{REFERENCES}

AVILA-STAGNO, J.; CHAVES, A. V.; HE, M. L.; HARSTAD, O. M.; BEAUCHEMIN, K. A.; MCGINN, S. M.; MCALLISTER, T. A. Digestibility, methane emissions, growth, fatty acid profiles, and carcass traits of lambs effects of increasing concentrations of glycerol in concentrate diets on nutrient. Journal of Animal Science, Champaign, v. 91, n. 3, p. 829-837, 2012.

BOSA, R.; FATURI, C.; VASCONCELOS, H. G. R.; CARDOSO, A. M.; RAMOS, A. F. O.; AZEVEDO, J. C. Consumo e digestibilidade aparente de dietas com diferentes níveisde inclusão de torta de coco para alimentação de ovinos. Acta Scientiarum Animal Sciences. Maringá, v. 34, n. 1, p. 57-62, 2012.

\section{BRASIL - MINISTÉRIO DA AGRICULTURA - Regulamento da Inspeção Industrial e Sanitária de Produtos de Origem Animal - RIISPOA, 2000.}

COSTA, J. C. C.; OSÓRIO, J. C. S.; OSÓRIO, M. T. M.; FARIA, H. V.; MENDONÇA, G. M.;ESTEVES, R. M.. Produção de carne de ovinos Corriedale terminados em três sistemas de alimentação. Revista Brasileira Agrociência, Pelotas, v. 15, p. 83-87, 2009.

FERNANDES, A. R.M.; ORRICO JUNIOR, M. A. P.; ORRICO, A. C. A.; VARGAS JUNIOR, F. M.; OLIVEIRA, A. B. M. Desempenho e características qualitativas da carcaça e da carne de cordeiros terminados em confinamento alimentados com dietas contendo soja grão ou gordura protegida. Revista Brasileira de Zootecnia. Viçosa v.40, n.8, p.1822-1829, 2011. Disponível em: <http://www.scielo.br/scielo.php?script=sci_arttext\&pid=S1516$35982011000800028 \& \operatorname{lng}=$ pt\&nrm=iso $>$ Acesso em: 27 fev. 2013. doi:10.1590/S1516-35982011000800028. http://dx.doi.org/10.1590/S1516-35982011000800028 
JUNG, B.; BATAL, A. B. Nutritional and feeding value of crude glycerin for poultry. 2. Evaluation of feeding crude glycerin to broilers. Journal of Applied Poultry Research, Champaign, v. 20, n. 5, p. 514, 2011. http://dx.doi.org/10.3382/japr.2011-00338

KREHBIEL, C. R.; CRANSTON, J. J.; MCCURDY, M. P. An upper limit for caloric density of finishing diets. Journal of Animal Science, Champaign, v. 84, n. 1, p. 34-49, 2006.

LAGE, J. F; PAULINO, P. V. R.; PEREIRA, L. G. R.;VALADARES FILHO, S. C.;OLIVEIRA, A. S.; DETMANN, E.;SOUZA, N. K. P.;LIMA, J. C. M. Glicerina bruta na dieta de cordeiros terminados em confinamento. Pesquisa Agropecuária Brasileira, Brasilia, v. 45, n. 9, p. 1012-1020, 2010. Disponível em: < http://dx.doi.org/10.1590/S0100-204X2010000900011> Acesso em: 28 fev. 2013. doi: 10.1590/S0100$204 X 2010000900011$.

LARSEN, A. C.; GOMES, B. M.; GOMES, S. D.; ZENATTI, D. C.; TORRES, D. G. B. Anaerobic codigestion of crude glycerin and starch industry effluent. Engenharia Agrícola, Jaboticabal, v. 33, n. 2, p. 341352, 2013.

LEÃO, J. P.; RAMOS, A. T.; MARUO, V. M.; SOUZA, D. P. M.; NEIVA, J. N. M.; RESTLE, J.; MORON, S. E. Anatomopatologia de amostras de bovinos alimentados com glicerol. Ciência Rural, Santa Maria, v. 42, n. 7, p. 1253-1256, 2012. http://dx.doi.org/10.1590/S0103-84782012005000046

MEALE, S. J.; CHAVES, A. V.; DING, S.; BUSH, R. D.; MCALLISTER, T. A. Effects of crude glycerin supplementation on wool production, feeding behavior, and body condition of Merino ewes. Journal of Animal Science, Champaign, vol. 91 n. 2, p.878-885, 2013. http://dx.doi.org/10.2527/jas.2012-5791

NATIONAL RESEARCH COUNCIL. Nutrient requirements of sheep. 6. ed. Washington: National Academy Press, 2007. 314p.

OSÓRIO, J. C. S.; OSÓRIO, M. T. M. Produção de carne ovina: Técnicas de avaliação “in vivo" e na carcaça. 3. ed. Pelotas: Universitária, 2005. 82p.

PALMQUIST, D. L.; MATTOS, W. R. S. Metabolismo de lipídeos. In: BERCHIELLI, T. T.; PIRES, A. V.; OLIVEIRA, S. G. (Ed.). Nutrição de ruminantes. Jaboticabal: FUNEP, 2006. p. 287-310.

PARSONS, G. L.; SHELOR, M. K.; DROUILLARD, J. S. Performance and carcass traits of finishing heifers fed crude glycerin. Journal of Animal Science, Champaign, v. 87, n. 10, p. 653-657, 2009.

PELlEGRIN, A. C. R. S.; PIRES, C. C.; MELlO, R. O.; MÜLlER, L.; CARVALHO, S.; LOPES, J. F. Glicerina bruta no suplemento e seus efeitos nas características da carcaça e nos componentes do peso vivo de cordeiros lactentes. Arquivos Brasileiros de Medicina Veterinária e Zootecnia, Belo Horizonte, v. 65, n. 5 , p. 1509-1518, 2013. http://dx.doi.org/10.1590/S0102-09352013000500032

SAMPAIO, I. B. M. Estatística aplicada à experimentação animal. 5. ed. Belo Horizonte: Fundação de Estudos e Pesquisas em Medicina Veterinária e Zootecnia, 2002. 265p.

SANTANA JÚNIOR, H. A.; FIGUEIREDO, M. P.; CARDOSO, E. O.; MENDES, F. B. L.; ABREU, F.; GEORGE, P.; ANDRADE, A.; VIANA, P. T.; ROSEIRA, J. P. S. Crude glycerin in supplement to primiparous lactating cows grazing on tropical pasture: nutritional and productive characteristics. Revista Brasileira de Zootecnia. Viçosa, v. 42, n. 2, p. 117-124, 2013.

SILVA, D. J. QUEIROZ, A. C. Análise de alimentos: métodos químicos e biológicos. 2 ed. Viçosa: Editora Universitária, 2002. 166p. 